\title{
THE HOUSING PROBLEM IN AMERICAN CITIES
}

\section{By Lawrence Veiller,}

Secretary, City Club, Deputy Tenement House Commissioner, New York, 1902-1904.

The great social and political problem of the times is the problem of the city. So grave has it become that many thoughtful men seriously question the adequacy of the democratic form of government, and believe that it is no longer suited to the conditions which prevail in many of the large cities of America. It certainly was not within the thought of the framers of the Constitution that we should have in a hundred years, cities containing several million inhabitants, drawing their population from every country of Europe, ignorant of our language and our customs, alien to our life and our thought. Forms of government, methods of education, conditions of life, suitable for a homogeneous nation such as existed in this country a hundred years ago may well be unsuited to the vast conconglomerate population of the large cities of to-day. The development of cities has come with the change from agricultural to industrial life, and the evils attendant upon that development have not been unanticipated. In England, from Elizabeth's time to the days of Charles II, every means within the power of those holding the reins of government was employed to prevent the growth of huge centres of population. The fear of the plague, the fear that the population would be "poisoned by breathing in one anothers' faces," that the police could not preserve order with such vast numbers of people, led to numerous efforts to prevent the growth of congested centres.

It is not perhaps generally known that as early as 1580 , a proclamation was issued in London prohibiting the erection within three miles of the city gates of any new houses or tenements upon sites where no former houses had been known to have been erected. 
Some years later, the authorities went so far as to order that only one family should live in each house, that houses erected within seven years and still unlet should remain empty, and that all unfinished buildings on new foundations should be pulled down.

In the effort to stem the tide toward the cities, in the reign of Charles I and even earlier, persons of means were orderd "Within forty days to resort to their several counties and with their families continue their residence there, and not to put themselves to unnecessary charge in providing themselves to return in winter to the said cities (London and Westminster), as it was the King's firm resolution to withstand such great and growing evil." How strong the feeling of the authorities was, can be gauged by the fact that in 1635, a Mr. Palmer, a large land-holder in Sussex, was fined one thousand pounds for disobeying the proclamation as to living in the country and remaining in London after the prescribed period. To our democratic minds these royal edicts seern strange and foreign, yet one is inclined at times to wish for the rule of a benevolent despot who would adopt similar measures. I suppose there is hardly one of those who have worked for many years in the congested quarters of our large cities who has not at one time or another desired that the city might be purified by fire, and that whole sections might be thus destroyed. But the thought has always been checked by the fear of what might rise, phœnix-like, from the ashes.

How far the fears of our English ancestors as to the effect of the development of large cities were justifiable can be determined by a consideration of conditions as they exist in America to-day. The conditions are by no means the same in different communities, though everywhere will be found the same underlyng evils, manifesting themselves in different places in somewhat different forms and varying greatly in extent and intensity. New York, cosmopolitan in its population, is equally cosmopolitan in its social problems. There will be found the problems of all other American cities, sometimes only in the germ, often, however, developed to an extent not dreamt of elsewhere. In the experience of New York may be found a lesson for every other city. There we have in their most impressive aspects the results of years of neglect and misrule. New York may well serve as a dreadful warning to other communities of what may come from present tendencies, if allowed to continue and if not checked in time. The main evils from which the poor in the large 
cities chiefly suffer are lack of sufficient light in their homes, lack of fresh air not only in the houses and courts but even in the public streets, unsanitary and filthy conditions in cellars, yards and courts, defective plumbing and inadequate and antiquated sanitary conveniences, overcrowding, excessive rents, lack of opportunity for healthful play for children, difficulties of social life that practically amount to a denial of opportunity for recreation, amusement and ordinary social intercourse, restricted opportunities of education, conditions of labor that seem almost industrial slavery, with constant temptations on every side to intemperance and vice as a welcome refuge from intolerable social and industrial conditions.

The causes of these evils are not to be sought in any one thing but in a multitude of influences operating through a considerable period of time. Some of the evils, it is true, are peculiar to one city; they may, however, at any moment appear in any other of our large cities. Others are common to all the cities of this country. Underlying them all will be found two main sources of evil-neglect and greed. Neglect on the part of the community, failure of its citizens to recognize evil tendencies as they develop, dangerous ignorance on the part of citizens and officials of what is going on within the city's gates-a feeling of safety and of confidence that all must be right, because they see little that is wrong, that things cannot be bad as long as they are hidden, a false civic pride that believes that everything in their own city is the best, a dangerous sort of apathy, content to leave things as they are, a laissez faire policy which brings forth fruit of unrighteousness. Greed on the part of those who desire to secure for themselves an undue profit on their investments, who are willing to traffick in human lives, to sacrifice the health, and the moral and social welfare of countless thousands so that they may become enriched thereby.

Of the many problems that press upon us for solution in our American cities none presents so many startling aspects as the problem of the housing of the working people, a question which has vexed old-world cities for over half a century, and one which we in America have been conscious of for seventy years. It might have been expected that in a new country under democratic institutions, planned on a broad and liberal scale, these municipal sores of the old world would not have appeared, but the causes which have produced them have been the same in New York as in London, or in 
Paris. Avarice and greed, combined with indolent nunicipal neglect produce the same results on both sides of the ocean.

It is only in very large cities that there exists what may be called a "tenement-house problem," although in nearly every city there is a housing problem. While a community is small, land is necessarily cheap and the evils of overcrowding, lack of light and air, lack of privacy, and the consequent physical and moral degradation which follow, are unknown. Traced back to its source, the beginning of bad housing conditions is the same in every city. It first manifests itself when two or three families occupy an old mansion, formerly the abode of one wealthy family, but no longer in a fashionable part of the city, and gradually falling into decay. As one house thus changes in a neighborhood, before long the whole neighborhood becomes similar, and we have a large population living in houses not adapted to the uses to which they are put, with the inevitable results of bad sanitation, overcrowding, and the numerous other physical and social evils which soon follow. Unscrupulous landlords and builders are quick to see that by crowding people closer and closer together they can greatly increase their profits, so that it soon becomes advantageous to them to build new buildings planned solely with the view of housing the greatest number of people upon the smallest area of land. Thus has arisen the great tenement-house system of our American citics. One of the greatest evils of this system is the evil of overcrowding, which one would expect to find only in those communities where there is a little vacant land or where the pressure of population is so intense as to render a scarcity of living accommodations unavoidable. This phenomenon, however, is by no means so limited, but is to be observed in nearly every one of our large cities, in such cities as Philadelphia, Buffalo, Chicago, Pittsburg and others where there is no scarcity of vacant land, nor any serious lack of sufficient living accommodations. Crowding is bad enough in its effect on the human race, but overcrowding is a word fraught with fatal significance.

There are two main manifestations of this evil which should be carefully distinguished. The one most commonly understood is that which relates to the overcrowding of the homes of the poor, the use of individual rooms or apartments by a greater number of people than is proper for the health or moral welfare of the inhabi- 
tants. It is this phase of the evil which exists to so great an extent in Europe, especially in London and in other English cities. The other phase which seems the larger question, serious as the former is, is almost unknown in the European cities, at least as it exists in New York. It is the overcrowding of limited areas with a densely packed population, and it is to this condition of affairs that I would especially direct attention. In one small portion of Manhattan Island, the district south of Fourteenth street and east of Broadway, dwell over 500,000 human beings, a population in itself greater than that of any other American city except Chicago, Philadelphia, St. Louis, Boston and Baltimore. A population greater indeed than the entire population of each of the following states and territories: Arizona, Delaware, Idaho, Montana, Nevada, North Dakota, Oregon, New Hampshire, New Mexico, Rhode Island, Utah, Vermont and Wyoming.

Were this city within a city composed chiefly of native-born citizens, speaking the same language, actuated by a common patriotism, and brought up under the same influences and surroundings, the consequences of this congestion of population would be serious enough, but where it is a city composed of people from every nation, alien to our life in nearly every way, ignorant of our language and brought up under conditions, social and political, that are entirely foreign to the ones under which they are now living, the results are fraught with the most serious consequences to the community. The mere herding together of such vast numbers of people in such close proximity would in itself engender a train of evils, but with the other disturbing factors added, the evils are greatly intensified.

No conception of the existing conditions can be obtained from any general statements. To say that the lower East Side of New York is the most densely populated spot in the habitable globe gives no adequate idea of the real conditions. To say that in one section of the city the density of population is $1, \infty 00$ to the acre and that the greatest density of population in the most densely populated part of Bombay is but 759 to the acre, in Prague 485 to the acre, in Paris 434, in London 365 , in Glasgow 350, in Calcutta 204, gives one no adequate realization of the state of affairs. No more does it, to say that in many city blocks on the East Side there is often a population of from 2,000 to 3,000 persons, a population equal to that of a good-sized village. The only way that one can understand the 
real conditions is to go down into the streets of these districts and see the thousands of persons thronging them and making them impassable. So congested have become the conditions of some of the quarters of this city, that it is not an exaggeration to say that there are more people living there than the land or the atmosphere can with safety sustain. The limits have not only been reached, but have long been passed. The city may not inappropriately be compared to the human organism, and thus considered it presents many interesting and impressive phenomena. Its streets are the veins and arteries through which the blood circulates, its parks are the lungs through which it breathes, and civic spirit and enlightened public sentiment are the directing intelligence which controls its movements and its life. Congestion has its effect on all of these physical parts of the city's organism. The gradual growth of some vile slum, such as was the old "Mulberry Bend," the congestion there of a degraded, semicriminal population stops the circulation of the city's healthful currents and ultimately gangrene sets in and the offending portions have to be cut out with the surgeon's knife. It is a serious mistake to let the conditions get so bad that so radical and so serious a remedy is necessary. The blood once poisoned is never entirely healthy again and it is only a little while before a second operation is necessary. Five years after we destroyed "Mulberry Bend" in New York, we were called upon to perform a similar task in Little Italy, and to-day one can place his hand upon as many as fifteen or twenty similar centres of decay. As with the blood, so with the lungs of the city; congestion there is as fatal as in the human body, and when the controlling intelligence is weakened, when congestion of the brain sets in, when civic spirit becomes dead, and public sentiment slumbers, paralysis of the whole organism follows as surely as it does with man.

The physical effects of overcrowding, while more observable, are no more serious than the social and industrial ones. There is not space to do more than merely indicate some of these evil effects. The destruction of home life, the weakening of the parental influence, the falling off of religious faith, the changed relation of the sexes, the absence of privacy, the intrusion of strangers upon the family life, the use in common of facilities of living where propriety and decency demand their restriction to a single family, the constant sight and sound of debasing influences from which escape is impos- 
sible-all have their weakening and lowering effect upon moral standards. The social consequences are almost as serious as the physical ones. In place of the home and the church, are the street, the dance hall and the saloon. Overcrowding operates industrially almost as much as it does physically. With the abnormal increase of population through immigration, a vast horde of workers each year are brought to compete with the workers already heie. Accustomed to lower wages and to a lower standard of living, they underbid them both socially and industrially, until the standards sink lower and lower. And from this industrial overcrowding we have that peculiar evil known as the "sweating system" by which men and women and even children are ground down in the treadmill of human labor, set to mean tasks and stunted intellectually and physically, forced by necessity to incessant toil.

One of the most serious effects of overcrowding and congestion of population is what I may be permitted to term social friction, the clashing of one life upon another, or rather of thousands of lives upon a single one; the disturbing nervous effect of the presence of so great a mass of human beings creating a social condition similar in many ways to the atmospheric conditions which exist before the coming of a thunder storm. This cannot be realized except by those who have lived in the more crowded districts of the city, where there is never quiet or stillness, but always the unceasing roar of the city's life. One is vividly reminded of Dante's "Strange tongues, horrible cries, words of woe, accents of anger, voices high and hoarse, and sounds of hands with them, were making a tumult which whirls forever in that air dark without change, like the sand when the whirlwind breathes." The mere ordinary processes of living are fraught with sucial friction at almost every point - the drawing of a pail of water, the playing of the children together, the simplest and most ordinary human functions become the occasions of strife and discord.

The change from the private dwelling to the crowded tenement is far-reaching in its consequences, and the effect is felt on the community physically, socially and morally. Its effect on the individual members of the community is also felt in these three ways. The effect, too, on democratic institutions is far-reaching and serious. The whole theory of our government is based on an intelligent electorate, upon the assumption that each citizen has a direct personal 
interest in the welfare of the country, that each member of the community is, to a certain extent, a taxpayer, with a personal interest in the affairs of that community. This was so when our government was founded, but it no longer is so. It certainly is not so in our large cities. The modern city is the most important factor in destroying a conservative point of view on the part of the working people. Where a man has a home and owns it, he has an incentive to work industriously, to be economical and thrifty, to take an interest in public affairs; every tendency makes him conservative. But where a man's home is three or four rooms in some huge building in which dwell from twenty to thirty other families and this home is only his from month to month, what incentive is there to economy? What is there to develop a sense of civic responsibility or patriotism? The change from the private dwelling to the crowded tenement, serious as it is in its effect on our native-born citizens, is even more serious when it affects the foreign elements of our population, who have come from rural, peasant life in Italy, Germany or Russia, where they have had ample space, abundance of light and air and absence from overcrowding, and have lived in sparsely-settled communities, and not in the close proximity which exists in cities. Such a family is suddenly compelled to make the transition from a life of this kind to the life of the crowded tenements, and in a country where everything is alien; where the language and customs are foreign and strange, and is suddenly called upon to adjust old habits to totally new conditions. This would be bad enough were some effort made to intelligently guide these people through their transition period, but no such effort is made. They are left to learn for themselves by bitter experience the difference between their new life and the old one, and because they do not immediately adjust themselves to this change we are apt to wonder, and to consider them an undesirable element of the population.

What must be the physical effect of this tremendous change in the living environment of those foreigners who come to these shores each year? What must be the contrast between the badly ventilated, overcrowded tenement house, and the simple dwelling of the small Italian village? The bad effect upon the community of a congregate form of living is by no means limited to the poorer people. WaldorfAstorias at one end of the town and "Big Flats" at the other end are equally bad in their destruction of civic spirit and the responsibilities 
of citizenship. It is but recently that the rector of one of New York's large churches complained that he found it impossible to reach the dwellers in apartment houses. The effect of living in this class of building, and even more so of living in hotels, is bound to have serious consequences for the nation. It means gradually the breaking down of family life; it means that children become undesirable; it means that the citizen, no longer being a householder, no longer comes into contact with the different branches of the municipal government and no longer has the same interest in the affairs of the community; he no longer has to deal with the city's Water Department; he no longer has to deal with its Health Department; with its Department of Street Cleaning; but all of his relations with the city government are taken from him, and in return for it he pays all these obligations, financially, by paying rent, but too frequently he pays them in no other way. The result must necessarily be that there are each year an increasing number of citizens who no longer have a direct interest in the affairs of government.

The housing problem is a threefold one, and, like human life, looks to the future, the present and the past. Its solution lies along three definite lines of action: First, as it affects the future. It is obvious that no house should be erected hereafter which does not have adequate light and ventilation, sufficient protection in case of fire, proper sanitary conveniences and make home life reasonably possible. The first step, therefore, in the solution of the housing problem, must be to prevent the erection in the future of bad types of houses, and to be sure that good types are erected.

The second direction in which the solution of the housing problem lies-concerns itself with the present, and is in seeing that existing tenement houses are maintained in a sanitary and safe condition; while the third direction looks to the past and seeks to remedy the errors of former years by compelling the reconstruction of the old houses so as to make them fit for human habitation.

In seeking to solve the housing problem, therefore, it is important that all three of these phases should be considered. Simply seeing that existing laws are enforced will do little good if the existing laws are inadequate and permit the erection of bad types of houses or permit existing houses to be maintained in an unsanitary condition. As most of the housing evils in our large cities have arisen because of the absence of wise restrictive legislation it is [256] 
obvious that the remedy for the conditions lies with the proper regulation by the state of the conditions under which such types of buildings may be constructed and operated. The directions effort should take, therefore, are toward legislative control and municipal regulation, and this is so in every large city. It is clearly the duty of the state to see that conditions shall not arise under which citizens shall be denied the ordinary conveniences of living. It is unquestionably the duty of the state to see that every human being is not deprived of his God-given right to light and air. In the same way it is the duty of the municipality to regulate the operation of such buildings and to see that in their management there are no conditions which are inimical to the public welfare. Notwithstanding this responsibility of government, activities should by no means be limited solely to those of governmental and municipal agencies. There is a very important field in housing reform for private effort, though the fields of public and private effort are distinct. There are many things which the government may do which cannot be done effectively by private citizens, and there are many things that it is better for the private citizen to do than for the government to undertake. It is quite impossible, for instance, for private effort to see it effectively that thousands of tenement houses are maintained in a sanitary condition. On the other hand, it is not a part of the function of government to engage in the construction and operation of tenement houses.

One of the most effective directions in which private effort may work is in the improvement of the old houses, a legitimate form of private effort and a proper field for the exercise of the activity of public-spirited citizens. This method of reform has been carried on with great success in London by that pioneer in the housing movement, Miss Octavia Hill, whose principles have become so wellknown as to give to the method her name. Her idea has been to buy an existing tenement house, not to disturb the tenants who are in it, but to gradually improve the houses and thus slowly change the standard of living of the occupants. It is an educational scheme of far-reaching consequences, and has worked with very great success in English cities. Similar efforts have been made in Philadelphia. In New York, Miss Ellen Collins, some forty-five years ago, purchased several dilapidated tenements in the Fourth Ward and then put them into operation on the Octavia Hill principle. Miss 
Collins' methods have brought with them great success for many years. Similar efforts have been made in New York at different times, but have not been uniformly successful. In Philadelphia an association of public-spirited men and women, known as "The Octavia Hill Association," was formed some years ago to carry on this work. The association now controls a number of tenement houses, which it manages and which it improves under these methods. In most of the large cities the field for work of this kind is practically unlimited. Great good could be accomplished if public-spirited citizens would buy old houses, make those structural changes in them that are necessary, letting light into the dark places, doing away with privy sinks and unsanitary plumbing, and making the houses fit for habitation; then selling them and repeating the experiment with other houses. A company which devoted itself solely to the management of tenement houses, if wisely directed, would be productive of excellent results.

There is a very strong feeling on the part of many persons in the community that the municipal ownership and operation of tenement houses would in some mysterious way solve the housing problem. In just what way has never been stated. The reason, I imagine, that the view prevails is because in certain European communities the municipality has undertaken such work and has, to some extent, succeeded. There is no more disastrous principle than this-the blind copying of what has been done in some other community under totally different conditions without regard to the forces that are at work in the individual community in question. It is, of course, conceivable why Socialists should strongly believe in the municipal ownership and operation of tenement houses, but it is hard to understand why persons not holding such views should advocate these theories. I must confess that I cannot see why the municipality should go into the business of providing housing accommodations any more than it should go into the business of providing food for the poorer members of the community, or clothes, or fuel, or in fact, not only the necessaries of life, but even the conveniences. If municipal tenement houses are desirable and are a proper function of government, why not municipal butcher shops, municipal grocery stores, municipal clothing establishments, municipal barber shops? The list might be added to indefinitely. If the municipality is to engage 
in such operations, which in the past have been limited to private enterprise, it must frankly recognize at the outset that it must occupy the entire field. Private enterprise will not compete with municipal undertaking, for it cannot; and when once the city undertakes the construction of tenement houses, the private builder will abandon the field and the city will be called upon to build all of such houses that are to be constructed. So tremendous an undertaking would this be that no government, as governments are constituted subject to the changes which invariably take place, would be able to carry on such a scheme.

Moreover, what is to be gained by having the government thus extend its functions? Do the advocates of such a scheme expect to demonstrate that tenement houses which are sanitary can be built and pay a fair rate on the money invested? This has been demonstrated over and over again in New York City in the past forty years. Do they expect that by this method they will be sure that all tenement houses that are erected in the future will be sanitary and provide proper accommodations for the persons that are to live in them? This result has already been attained in New York State by the present tenement house law, under which no house can be constructed which does not provide sufficient light and ventilation, proper sanitary conveniences and privacy. If the laws did not accomplish this result, the remedy would be to amend these laws. What other possible result could be achieved by the municipal ownership of tenement houses? It is often urged by the advocates of this plan that municipal tenement houses have been constructed and operated with great success in many English and Scotch cities and that, therefore, it should be done here. Municipal government in Great Britain is totally different from municipal government in America, and the peculiar political conditions which exist in New York and other American cities would be fatal to the success of municipal model tenements. We certainly can postpone so important an experiment until we have achieved perfect municipal government in regard to those functions of government which now engage the attention of our authorities; we can very wisely wait until the administration of the Charities Department has been made perfect, until the poor and sick and dependent are treated in the wisest way; we can wait until our street-cleaning system is made adequate; we can wait until our dealing with the liquor problem is 
satisfactory; we can wait until the administration of the health of the city is far more advanced than it is.

It is a rather strange thing that wherever an attempt is made in a new community to start a movement for housing reform, that it seems to be the first impulse of the public-spirited and charitable persons, active in such a movement, to build a so-called "model" tenement. I suppose it is due to the desire to see quickly definite and concrete results of their efforts. It is so much more satisfactory to most people to see a definite product crystallized quickly into brick and mortar than to wait perhaps for a period of four or five years to see larger results accomplished, only the tendencies of which could be seen at first. No one thing has probably done more to hinder the progress of housing reform in this country than this unfortunate impulse of well-disposed persons. I do not wish to be misundertood as under-rating the value of improved tenements, nor to deter persons from devoting their time and energy to such work. It is only when made an alternative for other methods of housing reform that it is seriously objectionable. When it takes the place of these it is strongly to be condemned.

Various efforts to solve the housing problem by building socalled "model" tenements have manifested themselves in this country in two forms-one by the building of such houses with the expressed intention of furnishing comfortable and pleasant living accommodations to the poorer members of the community, at rents lower than the rents that prevail in that part of the city for similar accommodations. Efforts of this kind must be regarded solely as charity and nothing else. Such efforts have in every case failed, and in every case deserve to fail. They are extremely undesirable, and exert as great a pauperizing influence upon the community as any of the other forms of out-door relief. They also invariably injure the cause of housing reform. The other form of effort to improve housing conditions by building "model" tenements is found in the work of those companies which, recognizing the unfortunate effect of charity, build "model" tenements with the determination that their work shall be conducted as a business enterprise, and that unless they can get a fair return upon the money invested, it shall not be carried on, and that the accommodations furnished shall never be at rates lower than the prevailing rents in the neighborhoods in which their buildings are located. The objections which 
apply to "model" tenements are materially minimized in quasi-philanthropic movements such as this. The great objection, however, to persons who desire to improve housing conditions, devoting their energies and means to the construction and maintenance of so-called "model" tenements, is that the same amount of energy and money directed in different channels would produce a hundred-fold greater results.

This has been strikingly illustrated in the history of housing reform in New York. In the period of sixty-three years, from 1842 to 1905 , there have been in the various parts of Greater New York about ten different groups of so-called "model" dwellings erected, equivalent, approximately, to about two hundred separate smaller tenement houses. That is, in sixty-three years, as a result of the effort of persons engaged in building so-called "model" tenements (many of which were by no means "model"), the net result has been the providing of about two hundred tenement houses of the ordinary size in which living accommodations are satisfactory. During the same period of time the speculative builders of the city, unrestricted by proper legislation, have erected approximately over fifty thousand indescribably bad types of tenement houses. Had the same effort which was expended in the erection and management of these ten groups of buildings, or two hundred houses, been expended in securing proper restrictive legislation and in watching its enforcement, there would have been to-day fifty thousand tenement houses equal in all respects to the two hundred socalled "model" tenements.

That this is not a theoretical view is fully sustained by the results accomplished by the New York State tenement house law, passed in Igor. In a period of eighteen months in New York City, there were erected under the provisions of this law 1,360 new tenement houses, all of which, from the point of view of adequate light and ventilation, proper sanitary conveniences, privacy and protection against fire, are fully equal to any of the "model" tenements erected in that city, and in many instances superior to them. This has been the result of the operation of wise legislation in the very limited period of a year and a half. What the results would have been if such a law had been operating for the past sixty years it is not difficult to imagine. Most of the housing problems that now exist in New York City would never have existed. It is for this reason, [26r] 
therefore, that so long as builders are allowed unrestricted to build improper types of tenement houses, that so long as existing buildings are not maintained in a sanitary condition, it is unwise for persons desiring to improve the living environment of the masses of the people to put forth intelligence, energy and force in the building of a single tenement house when the same energy and force expended more wisely will bring forth results a thousandfold more effective.

There are other reasons why the building of "model" tenements is not the most desirable form of effort in improving housing conditions in a community. Good intentions will not make a "model" tenement. The persons who are interested in such enterprises, as a rule, are totally unfamiliar with the actual conditions under which the poorer people live. They are also totally unfamiliar with the management of such property, and are, therefore, apt either to be extravagant in the construction of the building, to go to unnecessary expense, to waste space in unwise planning, or to so manage the house after it is erected that it becomes a failure both socially and financially.

The history of the first "model" tenement house in New York is singularly illuminating. It was built in 1855 by a company formed by a number of philanthropic persons who desired to improve housing conditions. The building was known as the "Workman's Home," and was situated on six lots on Mott and Elizabeth streets. The building contained thirty-seven different suites of rooms and provided accommodations for three hundred and forty-eight persons. In the description of the building it was stated that "every room is well ventilated, having air flues from each to the roof." When one considers that there were on each floor twenty-eight entirely dark and unventilated bedrooms, except such ventilation as might be obtained from the hallways or from a flue about the thickness of one brick in one of the walls, this statement seems rather astonishing. A few years after the building was erected it degenerated into one of the worst houses in the city, and was known as the "big flat," and became the resort of thieves, prostitutes and disorderly persons. In a similar way I might indicate the failure of many other movements for the erection of "model" tenements. In one case the building was so unwisely planned by the architect, so much space was left vacant and unnecessarily so, that it has been 
impossible, ever since the building has been constructed, for it to pay more than 3 per cent. upon the money invested. Another enterprise, which lasted about twelve years, has recently come to a close with a considerable financial loss to the investors. It is interesting to know that this property built as a "model" tenement within the last seventeen years has recently been sold and purchased by some real estate speculators, who have filed plans for materially altering the building so as to make it a paying proposition and up to the standard demanded by the tenants.

One of the earliest "model" tenement enterprises in this country has been extremely successful from the start. I refer to the model tenements of Mr. Alfred T. White, in Brooklyn; and the latest and most effectively organized movement of this kind, the work of the City and Suburban Homes Company, has been very successful. Wherever "model" tenements are built, however, it must be remembered that they are to a certain extent an institution. There is always the necessity of showing the buildings to persons who are interested from a charitable point of view, and self-respecting tenants naturally are bound to resent this intrusion upon the privacy of their home. The result is that in many cases the class of tenants gradually changes, the more self-respecting tenants seeking other quarters where they will not be intruded upon. The only justification for the erection of "model" tenements as a means of solving the house problem is to demonstrate in any community that the poor want good living accommodations, and that well-managed and well-constructed houses pay as a business proposition. I hesitate to comment upon the condition of the charitable education of a community where it is necessary to demonstrate that the poor want proper housing accommodations. Even in such cases the erection of a so-called "model" tenement house is a dangerous and expensive method of demonstrating this principle. Errors crystallized in brick and mortar are very difficult to remedy.

In order to understand the housing problem in all its phases, it is necessary to consider it from the point of view of both landlord and tenant, of owner and builder. In most considerations of this subject the financial side of the problem is too often omitted and yet no side is more important. Any movement for housing reform which leaves out of consideration the rights of property owners is necessarily bound to fail, and it unfortunately is too often the ten- 
dency of persons anxious to improve housing conditions to pay no attention whatsoever to this phase of the subject. They are so impressed with the great sanitary and social evils which exist, and their sympathy is so keenly aroused on behalf of the sufferings of the poor, that they are apt in their zeal to lose sight of these important considerations.

Much has been written in a popular way about the enormous profits accruing to the landlord in tenement house property and much abuse has been heaped upon his shoulders. On the other hand, the tenement house landlord has protested that his profits are small and that tenement house property as a rule does not pay. Both of these statements, strange as it may seem, are correct. In some cases large profits are reaped by tenement house owners, while in other cases investment in tenement house property is a losing venture. The reasons for this state of affairs are various. Unfortunately, accurate statistics as to the profits of owners of tenement houses have never been available, as few landlords have been willing to make public just what their income from such property is. If the system of building tenement houses on speculation could be done away with, it would result in a great deal of benefit to the tenants and would be a most important factor in lowering excessive rents and removing many of the inconveniences and discomforts from which tenants suffer. The fact that the tenement houses are built by persons whose sole desire is to sell them as soon as they are built, and who, therefore, have no interest in building well, so that the house will last and require few repairs, is responsible for the flimsy manner in which such houses are generally constructed. The sole purpose of the ordinary speculative builder is to make the house appear to be substantial when, as a matter of fact, as many purchasers can testify to their sorrow, the bills for repairs in a new house are extremely heavy during the first years of its occupation and increase in geometrical ratio during succeeding years. The result is that the tenants have to suffer because, of course, the landlord is bound to get back all of his expenditures in the form of rents.

Another tendency which has its unfortunate effect upon rents is the constant speculation which goes on in some cities in tenement house property, such houses changing hands frequently-as many as ten times in one year-and each time the new landlord seeks to raise the rents. The question of profits is one concerning which it is almost 
impossible to get accurate information. Few landlords are willing to divulge the details of the management of their property. The profits on a house depend also on the wisdom of the purchase; in many cases large profits are made, in some cases as high as from I5 to 20 per cent. These, however, are the exceptions. The average net return on tenement property in New York, so far as can be ascertained, is between 5 and 6 per cent., which is indeed a very fair return on the money. In many other cases, however, tenement house property pays no more than 2 or 3 per cent., and in some cases is a losing venture. It is easy to understand why this should be so, when one considers that the original purchase may have been unwise and the investor may have paid a price for his property far in advance of its real value and that, therefore, it is impossible for him ever to secure an adequate return upon his investment. Tenement owner's profits would be very largely increased if the class of persons who own tenement houses were more intelligent and gave greater consideration to the convenience and comfort of their tenants. In the ordinary tenement there is a very large loss each year from bad debts of tenants who are unscrupulous or dishonest and who do not hesitate to let their rent run for two or three months and then suddenly leave the house with the landlord unpaid. This evil is a very great one, so great indeed that it is a common saying among the tenement-house population that "it is cheaper to move than to pay rent." The unfortunate part of this condition of affairs is. that the self-respecting tenants who do pay their rent promptly, are made to suffer for the failure of the dishonest tenants to pay their just obligations, as in every case the landlord recoups himself for these losses by assessing the loss upon the other tenants in the house in the form of an increased rental. If more landlords would adopt the practice of thoroughly investigating the character of their tenants before accepting them as tenants, there would be fewer losses of this kind and rents generally would be lower, and both landlord and tenant would benefit thereby. The only persons who would suffer would be the rent dodgers.

Effort toward housing reform must seek, so far as it is possible, to offset the present tendency to concentrate in large cities, and there must be, if democratic institutions are to prevail, an organized effort to distribute the population and set the tendency back to rural or semi-rural communities. There is not the slightest reason why the 
greater part of our tremendous foreign population, which has come from rural peasant life in Europe, should not continue in similar rural peasant life in this country-in fact, there is every reason why it should. Thus far, there has been hardly any effort made to direct the careers of these foreigners along these lines. Such effort as has been made has been successful on the whole, but it has been done on so small a scale that, of course, its effect has only been slightly felt.

There is much misconception on this subject, and we ought to at once free our minds of the popular belief so often expressed by many of the well-to-do persons of the community that "the poor ought to live in the country." The reasons why the poor live in the city are undoubtedly the same reasons that account for the presence of the rich in the city-they like city life; and were indeed the great majority of the working people to remove from the city, the more prosperous members of the community would find themselves seriously embarrassed. No effort to stem the tide toward the cities or to turn it back to the country can succeed, which does not clearly recognize the fact that people are social in their nature and that they reside in cities because of the social opportunities which are to be found there. It is important, therefore, in such work to make rural communicaties, so far as possible, social centres. The Italian peasant has no special desire to live in a crowded tenement house, provided he is given an equivalent for the social atmosphere that he finds in the tenement districts. He had such equivalent in his native village; there the public square was the social centre. This principle has been very clearly recognized by a number of employers of industry who, in order to improve the quality of the workmanship in their factories and to secure continuity of service among their employees, and primarily because of their recognition of the fact that their workers are human beings, and not merely machines, and have an intellectual and spiritual side to their natures, have gone out of their way to provide for their employees, not only improved housing conditions, but social and educational opportunities of a high order.

Many people who are conscious of housing evils and who are desirous of improving the conditions under which the poor live are often handicapped by a lack of knowledge of how to proceed in attempting to remedy them. The best intentions in the world with- 
out proper knowledge and judgment, not only will not accomplish reforms, but may indeed do positive harm. It is important, therefore, to know how to start a movement for housing reform in any community. The essential thing first, is to know exactly and in detail just what the conditions are that it is sought to remedy. It would seem that this is elementary and that few persons would attempt to remedy conditions without this knowledge, but there is probably nothing more difficult to accomplish than to impress upon persons who desire housing reform, the necessity of knowing the facts before they seek to prescribe the remedies. Of course, in every community the facts are known in a general way, but this is not what is meant. The facts must be known in a strictly accurate and scientific way; there must be no guesswork.

The first step in such movements is, in every case, the formation of a citizens' committee to carry on the work of investigation and agitation for reform. Great care should be taken in selecting the members of such a committee. The committee's function is a twofold one: First, to act as an intelligent jury in passing upon the reports and recommendations of its trained investigators; second, as a body to influence public opinion. The committee should be selected, therefore, from persons who are prominent in the community and whose names will inspire confidence. Such a committee should always be composed of the leading and representative citizens of the community. A committee of this kind should also include persons familiar, to a greater or less degree, with the various sides of the housing problem; there should always be on the committee a capable architect, a practical builder, a prominent real-estate man, a physician, a lawyer, a representative of the leading charitable society of the city, a settlement worker where settlements exist, and where it is feasible, a representative of the local health department and the local building department. Such persons will bring to the service of the committee expert knowledge and advice along the lines of the special experience of each. Moreover, a committee thus constituted will have peculiar weight with the public. The public will naturally feel that recommendations made by a body of this kind will be eminently practicable and can be relied upon. By thus wisely choosing the committee, a large part of the battle is won at the start, because public sentiment is all-essential to every social reform. After such a committee has been organized, its next step $\left[26_{7}\right]$ 
is to employ a trained and expert investigator who can not only carry out such plans as may be made by the committee, but who can also originate plans and suggest to the committee methods of investigation. A committee had far better postpone its work for a year or even two years in order to obtain the services of such persons, than to undertake an investigation without a proper executive. When such executive has been secured, the first step is to become familiar with the experience of other communities in attempting to cope with housing problems. There is an unfortunate tendency in many smaller cities, perhaps a form of false civic pride, which leads them to disregard the experience of other communities, feeling that they are entirely able to handle the problems involved in their particular cities and that they do not need the advice of other and larger cities. This is a fatal error and is bound to have its effect. There is, however, danger of running to the other extreme and of slavishly copying the forms of effort which have been successfuly carried on in other communities. The most striking illustration of this kind and a delightfully ludicrous one, was in a small seaport town not far from Boston, where some ladies who were anxious to do effective work with the poorer children of the place (having learned of the very successful work done in New York and Boston with sand gardens for the younger children), prepared elaborate plans for the construction of similar sand gardens in their own town, until one of the wiser members suddenly called attention to the fact that it would perhaps be easier for the children to go down to the beach, which was but a short distance, and play in the sand there. Exactly similar forms of foolish adherence, in every detail, to the experience of other communities is found in almost every instance in which housing investigations have been made in this country.

It is a very serious mistake to imagine that the exact methods and remedies which have been framed to meet the peculiar conditions in a city like New York, for instance, are desirable or applicable to conditions in a city like Boston or Philadelphia. A forcible illustration of this tendency was had shortly after the creation of the new Tenement House Department in New York. As soon as its success seemed to be established, persons in Boston at once desired to establish a similar department in Boston, without considering whatever whether such department was necessary, but apparently [268] 
actuated solely by the view, "as long as this was a good thing for New York, it should be a good thing for Boston."

The directions that a housing investigation should take are three in number: Sanitary, structural and social. Such investigation should also look in three directions: To the future, to the present to the past. The sanitary investigation must concern itself necessarily with questions of plumbing, drainage, the adequacy of closet accommodations, sewage disposal and similar questions. It must also consider questions of light and ventilation, the health of the community, prevention of disease and overcrowding. The structural investigation should consider the materials out of which houses are built, the methods of building, their safety, protection in case of fire, conditions of repair and similar conditions, while the social effects of existing conditions should be studied from almost every point of view. Such an inquiry should involve the question of rents, occupations, the lodger evil, congestion of population, foreign colonies, opportunities for recreation and play, bathing facilities, school facilities, and many other educational questions.

An investigation into housing conditions should also look toward the future development of the community and should frame remedies by which, in future, no bad types of houses can be erected; should carefully study existing tendencies, and where it finds those tendencies working in unfortunate directions, should recommend methods to curb them or divert them into other channels; it should also consider the past, and where necessary, frame methods by which the errors of former years can be remedied.

No piece of work in connection with housing investigation is of more importance than the making of the investigation schedules and no portion of the work more difficult. Upon the skill and care with which such schedules are made, will depend to a large extent the efficiency of the investigation to be carried on, and there is unfortunately an extremely limited number of persons who have any particular knowledge upon this subject. I should advise every group of people who are contemplating starting a movement for housing reform, to devote several months to this one piece of work alone before starting their actual investigations. It is not possible within the limits of this paper to describe the main points to be considered in making such schedules. I shall, however, call attention to one or two salient points: First, that such schedules must always be a 
card system; second, that the size and shape of the card is extremely important and that a card of about $5 \times 8$ inches in size will be,found to be the most satisfactory; third, that the method of arrangement of the various inquiries upon the card is of the greatest importance -there should be a logical arrangement by which the investigator may go from one part of the building systematically to the other, checking up the various points in his natural progress through the building; that is, proceeding either from the cellar to the roof, or from the roof to the cellar, but not in any event having to jump around and consider at one time matters that relate to the roof or upper stories and then consider matters relating to the cellar, and then to have to return to the upper stories for some particular point. Another point which should be carefuly considered is that the amount of writing to be done on a schedule by the investigator should be minimized, and that the various answers to each question should, as a rule, be anticipated in the schedule, and the appropriate answer checked by the investigator. This is of great importance and is not usually considered in such investigations, the more popular method being to allow each investigator to write his own answers to every specific question. The result is, in such cases, that it is almost impossible to get any uniformity of results, owing to the variation of judgment among the different investigators. In answering inquiries as to cleanliness, a numerical percentage scale, indicating various degrees of cleanliness, should be adopted; thus, for example, very clean conditions might be represented by 100 ; clean, by 80 ; somewhat dirty, by 60 ; dirty, by 40 ; very dirty, 20 , and filthy, 0 . In regard to the presence or absence of rubbish, to use another illustration, the answer of the investigator should be limited to one of three conditions, and such answer may be very wisely confined to the terms, "free," "some," "much." Similarly, in regard to repairs -the investigator's answer should be limited to the terms, "good," "fair" and "bad." In general, wherever it is possible to describe conditions on a percentage basis, it is desirable. The great failing with most persons who are making up investigation schedules is that they leave entirely out of consideration the work that is to be done in the office in tabulating the results of such investigations. This is almost as important as the work which is to be done in the field and, as a rule, in any important investigation, takes almost as much time. 
A word in regard to the considerations to be borne in mind in such investigations in formulating a report. The tendency generally in writing reports of this nature is to make them too technical or academic, and while presenting unquestionably the results of the investigation, they are, in many cases, so unfortunately presented as to be uninteresting to the general public. Social workers should never lose sight of the fact that the purpose of an investigation of housing conditions in any community, is primarily to frame remedies for their reform, and that, as a rule, such remedies .will in the main be found in legislative action. It is essential, therefore, that in preparing a report of the work done and of the conditions found, such report should be popular in form and should hold the interest of the general public. It should, however, at the same time, be scientific in spirit; it should not attempt to prove preconceived ideas, but should simply set forth the facts as found and should never be willing to misrepresent them or to color them. There is often danger on the part of the persons writing such reports, because of their familiarity with the subject, of taking for granted that the public is also familiar with the conditions. This is a very serious danger and one to be carefully guarded against. The public as a rule possesses no knowledge of these conditions, and therefore it is essential to tell many things which seem elementary. It is also wise, wherever it is possible, to use photographs, illustrating the particular evils which need to be remedied, and the human element should not be omitted. The general public is, as a rule, far more interested in the people than in the physical conditions, and the successful report must carefully harmonize these elements. It also must consider not only the immediate purpose of the report in making plain the existing evils and creating a sentiment which will demand their remedy, but that it must of necessity have an important historical value and play an important part in the future education of the community.

Although the agitation for housing reform has been carried on in New York City for over sixty years, there has been little real progress made until recently. As a matter of fact, the conditions to-day in New York are far worse than they were in 1842 , when the first important movement for housing reform was started. The failure to accomplish more has been due chiefly to the lack of continuous effort. The efforts have been spasmodic, and in nearly every case at intervals of ten or five years. It is one of the 
most difficult and complicated social problems in existence and requires constant and continuous attention. The mere passage of some piece of remedial legislation will be of little value, unless such legislation is properly enforced. Let no one who is anxious to improve housing conditions, enter upon a movement for housing reform carelessly, thinking that it is a light task which he has undertaken. If the conditions are such that it is necessary to act at all, it will be found that there is plenty of work to be done for many years to come-in fact, the very greatest service that citizens can often contribute to the cause of housing reform, is after the particular legislative reform has been accomplished. Questions of interpreting the new law frequently arise, and the knowledge and experience of the persons who have framed the law will be found of the greatest moment in such emergencies. It is also extremely important to be sure that the laws are properly enforced, and unfortunately, one cannot be sure that any law is enforced in most of our American cities, unless citizens are willing to devote their attention to this subject. Any piece of tenement-house legislation in any community is necessarily experimental, and the framers of such reforms should, with an open mind, hold themselves ready to watch the effect of their recommendations and be prepared to recommend such changes as experience shows to be necessary. The law may easily in some respects be too drastic; in other respects it may not be sufficiently severe. In either event its effect should be studied by its friends and changes in it should be made by them, and not by the enemies of reform. If the friends of the reform have not sufficient interest in it to watch its enforcement and to study its defects and remedies, they can be quite sure that the enemies of reform will control its amendment and ultimately nullify its provisions. 